УДК 338.3

\title{
КОМПЛЕКС ЗАХОДІВ ЩОДО ЗАБЕЗПЕЧЕННЯ ЕФЕКТИВНОГО УПРАВЛІННЯ ВИСОКОТЕХНОЛОГІЧНИХ ВИРОБНИЦТВ В УКРАЇНІ
}

\author{
Дикань В.В., д.е.н., доцент (УкрДАЗТ)
}

У статті доведено, щзо Украӥна знаходиться на рівні індустріального суспільства. Ретельно досліджені причини такого стану та обтрунтована необхідність розробки комплексу заходів щуодо забезпечення ефективного управління високотехнологічних виробництв в Украӥні. Виділено, щзо в Украӥні механізми управління розвитком високотехнологічного виробництва слід формувати на макро-, мезота мікрорівнях. Детально опрацьовано кожен з виділених рівнів. Дослідження причинно-наслідкових зв'язків та існуючого конщептуального базису стало фундаментом для розробки комплексу дієвих заходів щзодо забезпечення ефективного управління високотехнологічним виробництвом в Украӥні.

Ключові слова: індустріальне суспільство, ефективне управління, високотехнологічне виробництво, механізм управління.

\section{КОМПЛЕКС МЕРОПРИЯТИЙ ПО ОБЕСПЕЧЕНИЮ ЭФФЕКТИВНОГО УПРАВЛЕНИЯ ВЫСОКОТЕХНОЛОГИЧНЫХ ПРОИЗВОДСТВ В УКРАИНЕ}

\author{
Дикань В.В., д.э.н., доцент (УкрГАЖТ)
}

\begin{abstract}
В статье доказано, что Украина находится на уровне индустриального общества. Исследованы причинь такого положения и обоснована необходимость разработки комплекса мероприятий по обеспечению эффективного управления высокотехнологических производств в Украине. Выделоно, что в Украине механизмы управления развитием высокотехнологического производства следует формировать на макро-, мезо- и микроуровнях. Подробно обработано каждый из выделенных уровней. Исследование причинно-следственных связей и существующего конщептуального базиса стало фундаментом для разработки комплекса действенных мер по обеспечению эффективного управления высокотехнологическим производством в Украине.
\end{abstract}

Ключевые слова: индустриальное общество, эффективное управление, высокотехнологичное производство, механизм управления.

\section{SET OF MEASURES TO ENSURE EFFECTIVE MANAGEMENT OF HIGH- TECH INDUSTRIES IN UKRAINE}

\author{
Dykan V.V., Ph.D., associate professor (USA of RT)
}

It is proved that Ukraine is on the level of industrial society. The reasons for this situation and the necessity to develop a set of measures to ensure the effective management of high-tech industries in Ukraine. It is proved that in Ukraine control mechanisms tech Industrial. Development should be designed at the macro, meso and micro levels. More processed each of the selected levels. Investigation of the cause-effect relationships and existing conceptual basis was the foundation for the development of a set of effective measures to ensure the effective management of high-tech manufacturing in Ukraine.

Keywords: industrial society, good governance, high-tech production, management mechanism.

Постановка проблеми. На сьогоднішній день високотехнологічне виробництво в Україні опинилося на межі виживання. Значно погіршилися стратегічні перспективи розвитку України через слабкий рівень діяльності внутрішнього ринку, низький рівень конкурентоспроможності вітчизняного виробництва та занепад національної економіки.

Розвиток високотехнологічних галузей стає визначальним для інтенсивного типу економічного відтворення, адже перехід на випуск високотехнологічної продукції супроводжується зниженням матеріаломісткості та енергоємності виробництва, зростанням продуктивності праці і відповідно підвищенням конкурентоспроможності країни. Сьогодні беззаперечним $є$ той факт, що високотехнологічне виробництво $\epsilon$ головним фактором підвищення зайнятості населення та рівня заробітної плати, що у свою чергу обумовлено інтенсивним зростанням світового виробництва й обсягами експорту високотехнологічної продукції. Таким чином, всі 
ці проблеми набули особливого значення сьогодні, коли Україна стоїть перед історичним вибором стратегії свого розвитку.

Аналіз останніх джерел та публікацій. Дослідженню поточного стану та ключових проблем розвитку промисловості України присвячено праці таких вітчизняних вчених, як Ареф'євої О., Амоша О., Бабича В., Диканя В., Федулової Л. [1-5]. У працях цих авторів виділено значення та підкреслено необхідність розвитку високотехнологічного сектору у вітчизняній промисловості, оцінено стан вітчизняних високотехнологічних виробництв тощо. Втім, додаткової уваги потребують питання пов'язані 3 формуванням та реалізацією комплексу заходів щодо забезпечення ефективного управління розвитком високотехнологічних виробництв в Україні.

Mema cmammi. Розробка комплексу заходів щодо забезпечення ефективного управління високотехнологічних виробництв в Україні.

Виклад основного матеріалу. Зараз Україна знаходиться на рівні індустріального суспільства, про що свідчать відсталі від світових аналогів технології, техніка, рівень швидкість удосконалення яких не витримує критики, а також структура формування ВВП, де висока питома вага належить добувній промисловості та сільському господарству (в постіндустріальному суспільстві сектору високих технологій та інновацій). Так, якщо у 1991 р. в галузевій структурі валової доданої вартості питома вага промисловості складала 42,3\%, у 1999 р. - 32,8\%, а за підсумками 2013 р.- 22,3\%. При цьому питома вага обробної промисловості в структурі валової доданої вартості за видами діяльності в обсязі ВВП склало усього 14,1\%. Причина такого занепаду, а відповідно, втрати лідерства української промисловості обумовлена, перш за все, розладом ресурсної бази, не дивлячись на те, що за період з 2000-2013 рр. в економіці України були періоди, як істотного підйому (до 2008 р.), так й суттєвого погіршення ситуації (криза 2008-2009 рр.)[6]. Однією 3 головних перешкод у розвитку високотехнологічних виробництв в Україні є спад рівня випуску висококваліфікованих спеціалістів в сфері промислових видів діяльності. Статистика показує, якщо у 2008 р. українські ВНЗ випускали 101,3 тис. молодших спеціалістів, бакалаврів, спеціалістів та магістрів, то вже у 2013 р. всього 82,8 тис.чол, що на 18,5 тис.чол менше. Це свідчить про те що, на фоні зниження ресурсного потенціалу промисловості, нація послідовно втрачає кваліфіковані кадри в сфері промислових видів діяльності. Через це, в Україні спостерігається низький рівень поєднання інтелектуальних ресурсів 3 новітніми технологіями, що не тільки визначають перспективи господарського зростання, але і $\epsilon$ показником рівня економічної незалежності i добробуту країни, іiі національного статусу. Таке поєднання сьогодні $є$ одним 3 найважливіших чинників, що визначають конкурентоспроможність національних економік. Перехід економіки на виробництво високотехнологічної продукції супроводжується кардинальним зниженням рівня матеріаломісткості й енергоємності виробництва, ростом продуктивності праці і підвищенням конкурентоспроможності економіки держави. Тому управління розвитком високотехнологічного сектора економіки стає визначальним чинником економічного зростання держави.

Як визначає Глазьєв С., управління розвитком складає необхідну підсистему нової системи регулювання економіки, що включає індикативне планування соціально-економічного розвитку, процедури вибору i реалізації пріоритетів господарської політики, механізми стимулювання НТП та інноваційної активності, інші інструменти державної політики. Без активно функціонуючої підсистеми розвитку заходи по збільшенню інвестиційної активності та пожвавленню виробництва будуть позбавлені цілеспрямованості, що може істотно понизити їх ефективність [7].

Управління розвитком є цілеспрямованим впливом керуючої системи на керовану з метою забезпечення процесу переходу від поточного стану соціально-економічної системи до кращого (досконалішого) порівняно 3 попереднім станом відповідно до поставлених цілей.

В Україні механізми управління розвитком високотехнологічних виробництв слід формувати на макро-, мезо- та мікрорівнях. На макрорівні таким $\epsilon$ механізм державного регулювання соціально-економічних процесів в регіонах, інструментами якого $є$ соціальноекономічна політика, нормативно-правове, інформаційно-консультативне та методичне забезпечення (рис.1) [8].

На мезорівні має місце механізм взаємодії підсистем інноваційної системи регіонів, інструментами якого $є$ інструменти кластерної технології, система регіонального замовлення на НДДКР, програми інноваційного розвитку регіонів та високотехнологічних виробництв, система фінансування науково-інноваційної діяльності високотехнологічних виробництв тощо.

На мікрорівні складовими комплексного механізму управління розвитком високотехнологічних виробництв $є$ : механізм управління конкурентним потенціалом, механізм управління економічним потенціалом підприємств та об'єднань, механізм управляння фінансовоекономічною безпекою підприємств та об'єднань, механізм використання та розвитку кадрового потенціалу підприємств та об'єднань, механізм 
управління інноваційними процесами підприємств та об'єднань, механізм управління технікооб'єднань, механізм управління технологічним розвитком підприємств та

підприємства та об'єднань та інші.

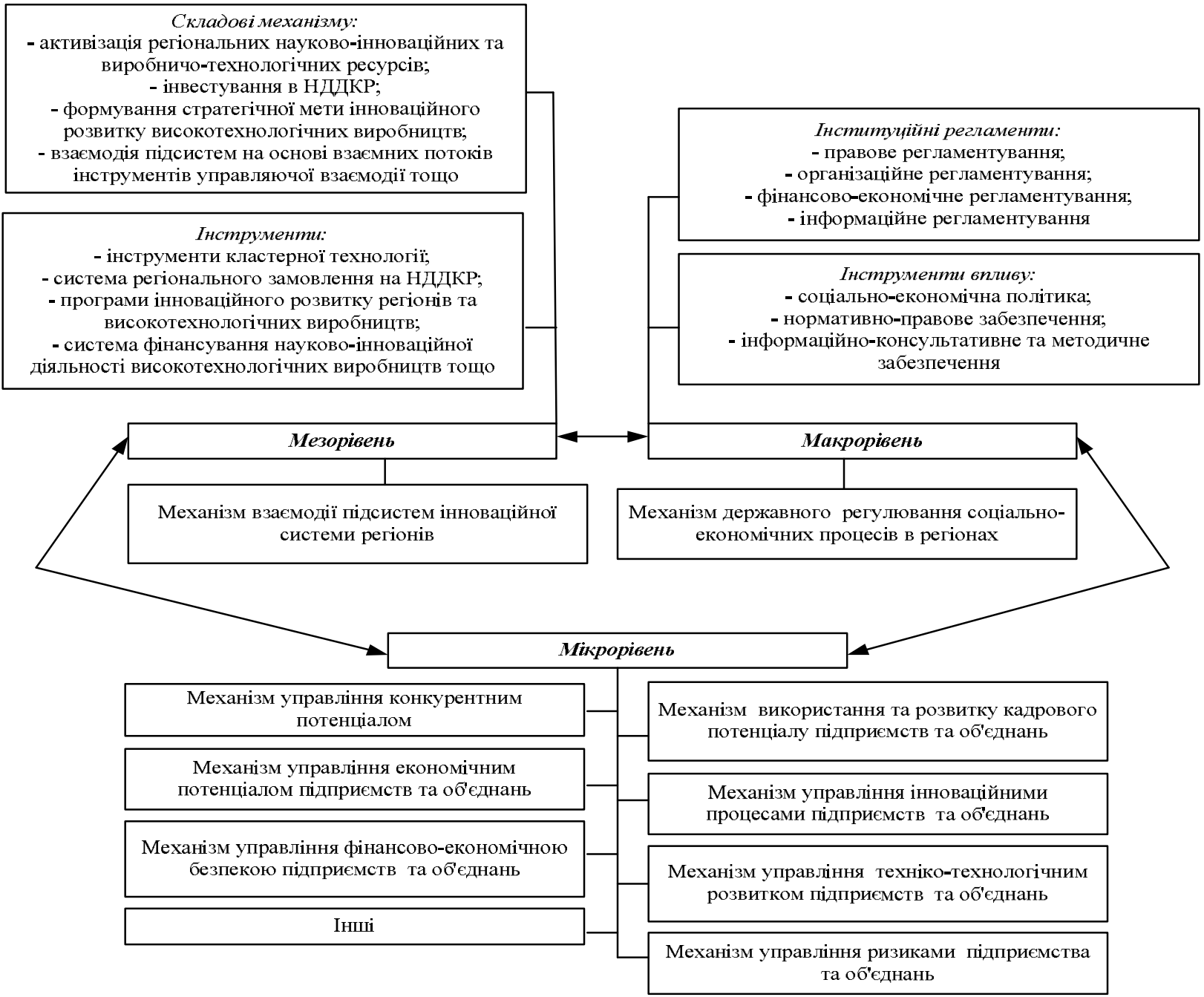

Рис. 1. Рівні механізмів управління розвитком високотехнологічних виробництв (авторська розробка)

Дослідивши рівні механізмів управління розвитком високотехнологічних виробництв, необхідно відзначити, що існуюче становище характеризується наявністю низки проблем, які носять системний характер та вимагають термінової реалізації ряду заходів, які б сприяли покращенню функціонування підприємств i забезпечили їх розвиток.

Серед основних причин, які стримують розвиток високотехнологічних виробництв в Україні, можна виділити слабкий рівень розвитку внутрішнього ринку, застарілу матеріальнотехнічну базу виробництва, низький рівень конкурентоспроможності вітчизняного виробництва, послаблення державного управління національною економікою, зокрема іiі промисловим комплексом, низький рівень інтеграції інформаційних та програмних комплексів, низьку привабливість на ринку праці. Bce це вимагає розробки концепції розвитку високотехнологічних виробництв України, яка забезпечила б економічне відтворення держави та змогла вивести іiї на новий конкурентоспроможній рівень. В загальному вигляді підходи щодо основ управління розвитком високотехнологічних виробництв в Україні подано на рисунку 2.

Метою розробки підходів щодо основ управління розвитком високотехнологічних виробництв України є визначення шляхів та засобів забезпечення якісного вдосконалення стану та структури високотехнологічних виробництв задля покращення якості продукції, що виготовляється та па підищення конкурентоспроможності на світовому ринку.

Основними завданнями є : 
1. Відновлення пропорційного розвитку національної економіки, забезпечення провідної ролі промисловості, повномасштабного розвитку внутрішнього ринку шляхом постачання вітчизняної техніки, технологій, сировини, проміжної та кінцевої продукції.

2. Підвищення ефективності та конкурентоспроможності промисловості, зокрема iii державного сектору.
3. Нарощування експортного потенціалу, пріоритетний розвиток вітчизняних підприємств експортерів продукції високого ступеня переробки та виробників імпортозамінної продукції.

4. Підвищення

інвестиційної привабливості.

5. Участь вітчизняних підприємств i організацій у проектах міжнародної кооперації.

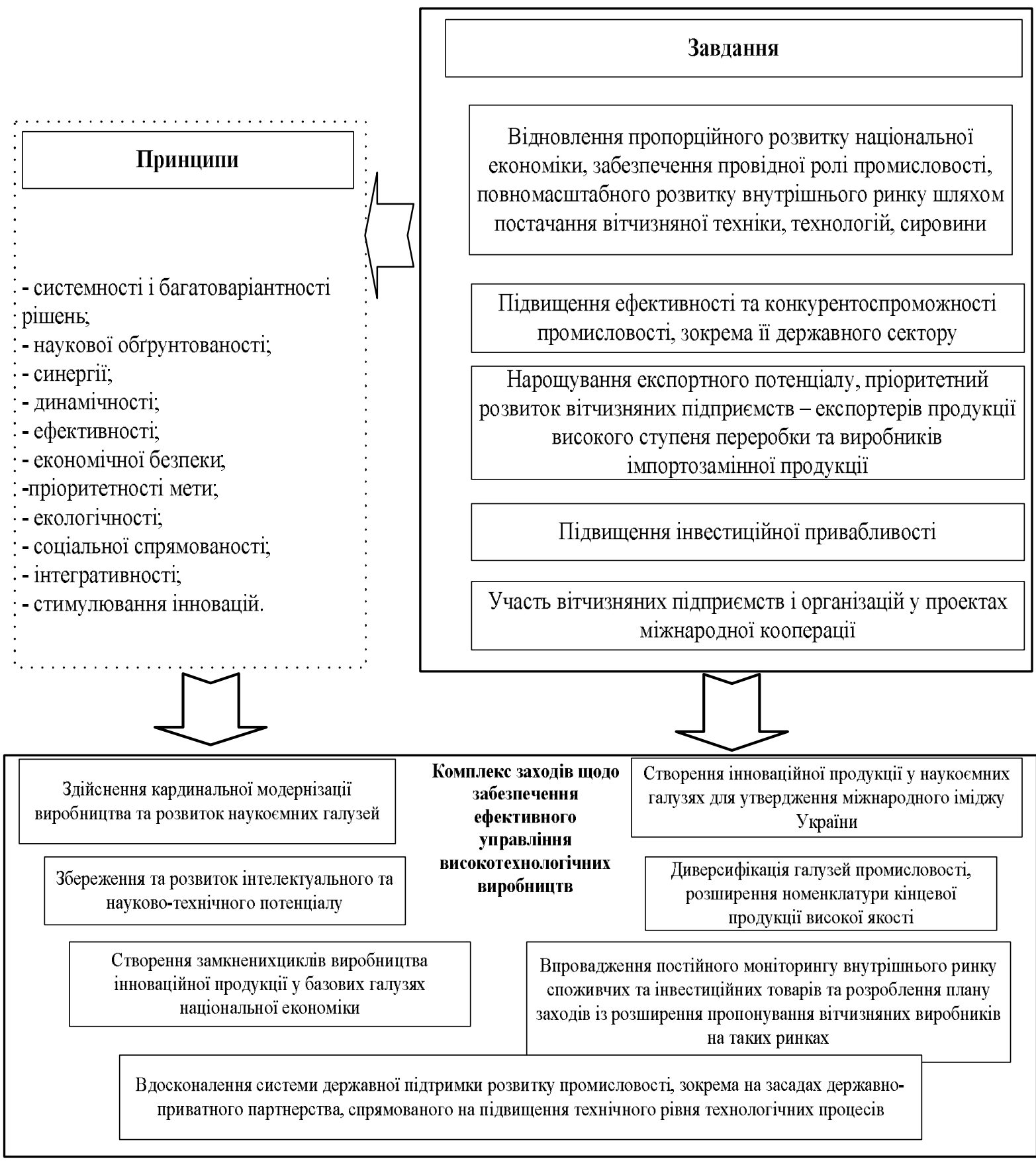

Рис. 2. Комплекс заходів щзодо забезпечення ефективного управління високотехнологічних виробництв в Украӥні (авторська розробка) 
Для досягнення поставлених завдань необхідно забезпечити реалізацію комплексу наступних заходів:

- здійснення кардинальної модернізації виробництва та розвиток наукоємних галузей,

- збереження та розвиток інтелектуального та науково-технічного потенціалу;

- створення замкнених циклів виробництва інноваційної продукції у базових галузях національної економіки;

- вдосконалення системи державної підтримки розвитку промисловості, зокрема на засадах державно-приватного партнерства, спрямованого на підвищення технічного рівня технологічних процесів;

- створення інноваційної продукції у наукоємних галузях для утвердження міжнародного іміджу України;

- диверсифікація галузей промисловості, розширення номенклатури кінцевої продукції високої якості;

- впровадження постійного моніторингу внутрішнього ринку споживчих та інвестиційних товарів та розроблення плану заходів із розширення пропозиції вітчизняних виробників.

В основу реалізації основних та забезпечувальних процесів управління розвитком високотехнологічних виробництв в Україні автор пропонує покласти наступні принципи, що складуть базис для досягнення якісних змін:

$$
\text { 1) принцип системності }
$$

багатоваріантності рішень, що розробляються дотримання вимог системного підходу в управлінні розвитком високотехнологічного виробництва, у тому числі цілеспрямованості управлінських дій, наявність контуру зворотного зв'язку;

2) принцип наукової обгрунтованості, що вимагає при підготовці та ухваленні рішень використання сучасних науково обгрунтованих методів, моделей і підходів до управління;

3) принцип синергії - кожне схвалюване рішення повинно розглядатися в комплексі 3 іншими рішеннями i управляючими діями для оцінювання можливого синергетичного ефекту та його наслідків;

4) принцип динамічності, що передбачає гнучкість і адаптивність системи управління до динаміки соціально-економічної системи регіонів та країни у цілому i його макроекономічного оточення;

5) принцип ефективності, що передбачає позитивні результати управляючої дії як для суб'єкту, так і для об'єкту управління;

6) принцип економічної безпеки дотримання вимог забезпечення безпеки (економічної, інвестиційної, виробничої, бюджетної тощо) при ухваленні управлінських рішень і здійсненні управлінських дій;
7) принцип пріоритетності мети, що забезпечує збалансованість розвитку високотехнологічного виробництва, відповідно до якого необхідно чітко збудувати ієрархію мети розвитку, що суворо підкоряється системі обраних пріоритетів;

8) принцип екологічності передбачає обов'язкову оцінку i мінімізацію негативних екологічних ефектів, пов'язаних 3 реалізацією управлінських рішень і підтримку заходів, направлених на підвищення екологічності функціонування високотехнологічних виробництв;

9) принцип соціальної спрямованості, згідно якому стратегічні рішення, що розробляються, програми i проекти в рамках стратегічного планування i управління на різних рівнях повинні бути направлені на підвищення якості життя населення, підтримку соціальної стабільності в регіонах;

10) принцип інтегративності, при якому реалізується механізм державно-приватного партнерства i дотримуються соціально-етичні норми;

11) принцип стимулювання інновацій, відповідно до якого необхідно забезпечити ефективну реалізацію нових інноваційних ідей i потенціалу в управлінських, економічних, екологічних, виробничих, соціальних i технологічних підсистемах високотехнологічного виробництва в умовах модернізаційних перетворень.

Висновок. Отже, запропонований комплекс заходів щодо забезпечення ефективного управління високотехнологічних виробництв в Україні $є$ базисом для якісного вдосконалення стану та підвищення економічного рівня держави і виступає методологічною основою для розробки відповідного програмного документу. Їх реалізація передбачає модернізацію промисловості, а також створення умов для піднесення вітчизняної науки та інноваційної сфери, що сприятиме підвищенню конкурентоспроможності національної економіки та надасть можливість побудувати високотехнологічну державу.

\section{СПИСОК ЛІТЕРАТУРИ}

1. Ареф’єва О.В. Політика управління оборотним капіталом підприємства: теоретичний аспект / О.В. Ареф'єва, Н.Ю. Соломіна // Агросвіт.- 2012. - №16. - С. 23 - 27.

2. Амоша О.И. Промышленная политика Украины: концептуальные ориентиры на среднесрочную перспективу / О.И. Амоша, В.П.Вишневский, Л.О. Збаразька // Экономика Украины.- 2009. - №12. - С. 4-13.

3. Бабич В.П. Розвиток соціальної сфери як передумова інноваційного розвитку науковотехнічного і виробничого комплексу регіону / В.П. 
Бабич, В.П. Третяк // Вісник Харківського національного університету: Зб. Наук. Праць. Режим доступу:

http://archive.nbuv.gov.ua/portal/natural/vkhnu/Ekon/ 802/08btrroz.pdf
4. Дикань
В.Л.
Забезпечення конкурентоспроможності підприємств: підручник / [В.Л.Дикань, Ю.Т.Боровик, О.М. Полякова та ін.].Харків: УкрДАЗТ, 2011. - 387.

5. Інноваційно-технологічний розвиток України: стан, проблеми, стратегічні перспективи: Аналітичні матеріали до Парламентських слухань [“Стратегія інноваційного розвитку України на 2010-2020 роки в умовах глобалізаційних викликів"] / [Л.І. Федулова, Ю.М. Бажал, І.А.
Шовкун та ін.]; за ред. Л.І. Федулової, Г.О. Андрощука; Ін-т екон. та прогнозув. НАН України. - K., 2009. - 196 c.

6. Статистичний щорічник України за 2013 рік. - К., 2014.- С.77;

7. Глазьев С. Управление развитием фактор устойчивого экономического роста [Электронный ресурс] / С. Глазьев. Режим доступа: http://vasilievaa.narod.ru/ptpu/5_4_99.htm

8. Дикань В.В. Забезпечення розвитку машинобудівного комплексу України в умовах створення промислово-логістичної системи: монографія /Дикань В.В.- Харків: УкрДАЗТ, 2013p. - С. 56.

Експерт редакційної колегії к.е.н., доцент УкрДАЗТ Зубенко В.О.

УДК 339.92

\title{
ПРІОРИТЕТИ РОЗВИТКУ АПК УКРАЇНИ ДЛЯ СТИМУЛЮВАННЯ ЗОВНІШНЬОЇ ТОРГІВЛІ СІЛЬСЬКОГОСПОДАРСЬКОЮ ПРОДУКЦІЕЮ В УМОВАХ АСОЦАЦІї 3 ЄС
}

\author{
Маханьова Ю.М., аспірант (ХНУ імені В.Н. Каразіна)
}

У статті проведено аналіз заходів Коалічійної угоди, Програми діяльності Кабінету Міністрів України на 2015-2020 роки, а також Стратегї сталого розвитку «Україна - 2020», спрямованих на стимулювання виробництва сільськогосподарської продукції для задоволення внутрішнього попиту $i$ розвитку експортного потенціалу. Обгрунтовано пріоритети розвитку АПК України, що стимулюватимуть збільшення зовнішньої торгівлі сільськогосподарською продукиією в умовах асоиіації з $E C$.

Ключові слова: сільськогосподарська продукція, агропромислове виробництво, зовнішня торгівля, угода про асоціацію з $Е$.

\section{ПРИОРИТЕТЫ РАЗВИТИЯ АПК УКРАИНЫ ДЛЯ СТИМУЛИРОВАНИЯ ВНЕШНЕЙ ТОРГОВЛИ СЕЛЬСКОХОЗЯЙСТВЕННОЙ ПРОДУКЦИЕЙ В УСЛОВИЯХ АССОЦИАЦИИ С ЕС}

\author{
Маханева Ю.Н., аспирант (ХНУ имени В.Н. Каразина)
}

\begin{abstract}
В статье проведен анализ мероприятий Коалиционного соглашения, Программы деятельности Кабинета Министров Украиньл на 2015-2020 годы, а также Стратегии устойчивого развития «Украина - 2020», направленных на стимулирование производства сельскохозяйственной продукции для удовлетворения внутреннего спроса и развития экспортного потенциала. Обоснованы приоритеты развития АПК Украины, которые будут стимулировать увеличение внешней торговли сельскохозяйственной продукичей в условиях ассоичаичии с ЕС.
\end{abstract}

Ключевые слова: сельскохозяйственная продукция, агропромышленное производство, внешняя торговля, соглашение об ассоциации с ЕС. 